\title{
Carbon Stocks across a Fifty Year Chronosequence of Rubber Plantations in Tropical China
}

\author{
Chenggang Liu ${ }^{1,+}$, Jiaping Pang ${ }^{1,2,+}$, Martin Rudbeck Jepsen ${ }^{3}$, Xiaotao L $\ddot{u}{ }^{4}$ and Jianwei Tang ${ }^{1, *}$ \\ 1 Key Laboratory of Tropical Plant Resources and Sustainable Use, Xishuangbanna Tropical Botanical Garden, \\ Chinese Academy of Sciences, Menglun 666303, China; chenggangliu@hotmail.com (C.L.); \\ pjp_0725@163.com (J.P.) \\ 2 Institute of Geographic Sciences and Natural Resources Research, Chinese Academy of Sciences, \\ Beijing 100101, China \\ 3 Department of Geosciences and Natural Resource Management, University of Copenhagen, \\ Øster Voldgade 10, DK-1350 Copenhagen, Denmark; mrj@ign.ku.dk \\ 4 State Key Laboratory of Forest and Soil Ecology, Institute of Applied Ecology, Chinese Academy of Sciences, \\ Shenyang 110164, China; lvxiaotao@gmail.com \\ * Correspondence: tangjw@xtbg.org.cn; Tel.: +86-0691-8715080 \\ + These authors contributed equally to this work.
}

Academic Editor: Mark E. Harmon

Received: 26 April 2017; Accepted: 7 June 2017; Published: 13 June 2017

\begin{abstract}
Transition from forest to rubber (Hevea brasiliensis Muell. Arg.) plantation has occurred in tropical China for decades. Rubber has been planted on 1 million ha to provide raw materials to the rubber industry. The role of various-aged rubber plantations in carbon (C) sequestration remains unclear. The biomass $C$ accumulation including latex $C$ and $C$ distribution in soil of five different-aged stands $(7,13,19,25$ and 47 years old) were examined. The total biomass $C$ stock (TBC) and total net primary productivity $\left(\mathrm{NPP}_{\text {total }}\right)$, whether with or without latex $\mathrm{C}$, had a close quadratic relationship with stand age. Regardless of stand age, around $68 \%$ of the $\mathrm{C}$ was stored in aboveground biomass, and $\mathrm{NPP}_{\text {latex }}$ contributed to approximately $18 \%$ of $\mathrm{C}$ sequestration. Soil organic carbon stock in the $100-\mathrm{cm}$ depth remained relatively stable, but it lost about $16.8 \mathrm{Mg} \mathrm{ha}^{-1}$ with stand age. The total ecosystem C stock (TEC) across stands averaged 159.6, 174.4, 229.6, 238.1 and $291.9 \mathrm{Mg} \mathrm{ha}^{-1}$, respectively, of which more than $45 \%$ was stored in the soil. However, biomass would become the major $C$ sink rather than soil over a maximal rubber life expectancy. Regression analysis showed that TEC for rubber plantation at 22 years is comparable to a baseline of $230.4 \mathrm{Mg} \mathrm{ha}^{-1}$ for tropical forest in China, and would reach the maximum value at around 54 years. Therefore, rubber plantation can be considered as alternative land use without affecting net forest ecosystem $\mathrm{C}$ storage. In addition to the potential $\mathrm{C}$ gains, a full set of ecosystem and economic properties have to be quantified in order to assess the trade-offs associated with forest-to-rubber transition.
\end{abstract}

Keywords: latex yield; net primary productivity; quadratic regression model; chronosequence; soil organic carbon

\section{Introduction}

Increasing atmospheric carbon dioxide $\left(\mathrm{CO}_{2}\right)$ concentrations and global climate change are of growing concern to humankind. The world's forests are a critical component of the terrestrial ecosystem and play a significant role in regulating the global carbon $(C)$ cycle by serving as $C$ sinks, thereby potentially mitigating future impacts of climate change [1]. Tropical forests represent about half of the global forest area and are believed to be the largest $C$ reservoir of terrestrial biota [2]. They hold approximately $470 \mathrm{Pg} \mathrm{C}$ in live biomass, debris, and soil organic matter, which is approximately $55 \%$ of 
the total C stored in the world's forests [3]. Large areas of naturally-regenerated tropical forests have been lost due to land use changes, which resulted in the emission of around $1.4 \mathrm{Pg} \mathrm{C}_{\text {year }}{ }^{-1}$ to the atmosphere during 1990-2010 ( 15\% of global anthropogenic $\mathrm{CO}_{2}$ emissions for that time period) [4]. In order to combat global warming and reduce $\mathrm{CO}_{2}$ emissions from land-use transition, especially due to deforestation and forest degradation, accurate and reliable estimates of $C$ sequestration in various forest ecosystems are needed [5].

Rubber tree (Hevea brasiliensis Muell. Arg.) is a cash crop that provides a variety of raw materials to industrial products. During the past decades, state-owned farms and particularly smallholder farmers have gained unprecedented wealth in southern China and elsewhere due to the rising global rubber prices and the sustainability of government subsidies, e.g., the latex return reached approximately 36,000 CNY ha ${ }^{-1}$ or 13,000 CNY per person in Xishuangbanna (Yunnan Province) in 2010 [6]. Accordingly, large areas of forests have been converted into rubber plantations in the tropics, resulting in major alterations in ecosystem $C$ dynamics due to deforestation and soil erosion $[7,8]$. Rubber plantations presently cover an area of 10 million ha in southeast Asia, out of which 1 million ha is in tropical China. The rubber-based income from these plantations may be decreased, however, due to the risk of falling latex prices, although it can be increased by the sell of stumpage when rubber trees have reached their latex-tapping lifespan [6]. To evaluate the trade-offs between ecological and economic functions, rubber transitions have been the subject of considerable study $[5,9,10])$. Rubber plantation C stocks in biomass and soil have been studied [11,12], but information on the C sequestration including its latex $C$ is still lacking, particularly in tropical China. Given the expansion area and the potential expansion rates in the future, a deeper understanding of $C$ sequestration in rubber plantation ecosystems is needed on the part of policymakers, managers, researchers and other groups in the scientific community.

C sequestration in forest ecosystems is affected by stand age, topography, climate, soil type, tree species, and management regime $[13,14]$. It has been known that the $C$ stored in tree biomass increases with stand age, but the trend may be different for the mineral soil C storage $[11,15,16]$. Several authors have revealed enhanced biomass $C$ in rubber plantations with stand age, ranging from 1.4 to $6.7 \mathrm{Mg} \mathrm{ha}^{-1}$ year $^{-1}$ [17-19], but these results excluded an important $C$ component that is stored in latex. Meanwhile, whether net primary productivity (NPP) is related to stand age is still not clear, because Kotowska et al. [10], for example, observed no obvious correlation between total biomass C and NPP when including latex yield. On the other hand, soil $\mathrm{C}$ pool might be independent of rubber age sequence. For example, in one study, soil organic C (SOC) stock under rubber plantation increased $1.13 \mathrm{Mg} \mathrm{ha}^{-1}$ year $^{-1}$ over 11 years [20], whereas in another study, a forest-to-rubber transition led to SOC stock loss by an average of $37.4 \mathrm{Mg} \mathrm{ha}^{-1}$ in $120 \mathrm{~cm}$ depth over 46 years [9].

Therefore, the objectives of this study were to: (i) quantify above- and belowground biomass $C$ as well as latex $C$ in five different-aged (7-, 13-, 19-, 25- and 47-year-old) rubber plantations; and (ii) relate SOC storage with increasing stand age. We hypothesized that (i) rubber biomass $C$ and its NPP including latex yield has a close quadratic relationship with stand age; and (ii) SOC stock will not be affected by stand age.

\section{Materials and Methods}

\subsection{Study Site and Plot Establishment}

The study site is located in Mengla County of Xishuangbanna, Yunnan Province, southwest China $\left(21^{\circ} 09^{\prime}-22^{\circ} 23^{\prime} \mathrm{N}, 101^{\circ} 05^{\prime}-101^{\circ} 50^{\prime} \mathrm{E}\right)$, which borders Myanmar and Laos at the source of the Mekong River. The region has a typical tropical monsoon climate with a rainy season (May-October) and a dry season (November-April). The mean annual rainfall is $1550 \mathrm{~mm}$, out of which $83 \%$ occurs in the rainy season. Mean annual evapotranspiration is $1200 \mathrm{~mm}$. Average relative air humidity ranges from $76 \%$ to $89 \%$. Mean annual air temperature is $21.5^{\circ} \mathrm{C}$. Temperatures often exceed $38^{\circ} \mathrm{C}$ during March 
and April when the relative humidity is below 40\%. The average annual number of sunshine hours is $1800 \mathrm{~h}$ with 170 foggy days a year.

Five adjacent rubber plantations with different ages were selected based on similar topography, management practices, and previous vegetation composition (dominated by Millettia sp., Syzygium sp., Castanopsis indica and Phoebe lanceolata) in January 2009. The rotation period for rubber plantation is about 40 years in this region due to high tree mortality caused by pests and disease [21]. We identified a chronosequence of rubber stands that were 7-, 13-, 19-, 25-, and 47-years of age. These different-aged stands were first tapped for latex when the trees were 7 years old. All five stands were located within an approximately $10-\mathrm{km}$ radius of each other. Three sampling plots $(25 \times 40 \mathrm{~m})$ were randomly established in each stand. Within each plot, diameter at breast height (1.3 m, DBH) and height for individual trees were measured using a diameter tape and a Haglöf Vertex clinometer, respectively. Topographical features of each plot, including elevation, slope and aspect, were recorded (Table 1).

Table 1. Stand and soil characteristics of the 7-, 13-, 19-, 25- and 47-year-old rubber plantations at Xishuangbanna, Yunnan Province, China.

\begin{tabular}{|c|c|c|c|c|c|}
\hline Stand Parameter & 7-year-old & 13-year-old & 19-year-old & 25-year-old & 47-year-old \\
\hline Longitude & $101^{\circ} 14^{\prime} 45.3^{\prime \prime}$ & $101^{\circ} 14^{\prime} 40.1^{\prime \prime}$ & $101^{\circ} 14^{\prime} 43.5^{\prime \prime}$ & $101^{\circ} 16^{\prime} 28.9^{\prime \prime}$ & $101^{\circ} 16^{\prime} 03.5^{\prime \prime}$ \\
\hline Latitude & $21^{\circ} 56^{\prime} 48.8^{\prime \prime}$ & $21^{\circ} 56^{\prime} 49.6^{\prime \prime}$ & $21^{\circ} 56^{\prime} 34.8^{\prime \prime}$ & $21^{\circ} 54^{\prime} 36.8^{\prime \prime}$ & $21^{\circ} 55^{\prime} 22.9^{\prime \prime}$ \\
\hline Elevation (m) & $580-595$ & $600-620$ & 560-570 & 570-580 & $550-570$ \\
\hline Slope $\left(^{\circ}\right)$ & 30-35 & $25-30$ & $25-30$ & $15-20$ & $0-5$ \\
\hline Aspect & Southwest & Southeast & Southeast & Southeast & Southwest \\
\hline Planting spacing $(\mathrm{m})$ & $2.5 \times 6$ & $2.5 \times 6$ & $2.5 \times 8$ & $2.5 \times 8$ & $2.5 \times 8$ \\
\hline Average DBH $(\mathrm{cm})$ & $9.3 \pm 0.7^{\mathrm{d}}$ & $15.5 \pm 0.8^{c}$ & $21.4 \pm 1.2^{b}$ & $24.9 \pm 0.7^{b}$ & $40.4 \pm 2.2^{\mathrm{a}}$ \\
\hline Average height (m) & $7.3 \pm 0.9^{c}$ & $13.9 \pm 1.0^{b}$ & $16.3 \pm 1.2^{\mathrm{ab}}$ & $17.2 \pm 0.8^{a}$ & $21.3 \pm 1.1^{\mathrm{a}}$ \\
\hline Density (plants ha ${ }^{-1}$ ) & $667 \pm 31^{a}$ & $637 \pm 26^{a}$ & $626 \pm 21^{\mathrm{a}}$ & $510 \pm 23^{a b}$ & $203 \pm 17^{b}$ \\
\hline Basal area $\left(\mathrm{m}^{2} \mathrm{ha}^{-1}\right)$ & $5.1 \pm 0.8^{c}$ & $11.3 \pm 1.0^{\mathrm{b}}$ & $21.9 \pm 1.8^{\mathrm{ab}}$ & $24.6 \pm 0.7^{\mathrm{a}}$ & $29.5 \pm 0.9^{a}$ \\
\hline $\mathrm{pH}$ & $6.5 \pm 0.2^{\mathrm{a}}$ & $6.4 \pm 0.1^{\mathrm{a}}$ & $6.0 \pm 0.1^{\mathrm{a}}$ & $5.7 \pm 0.1^{a b}$ & $5.4 \pm 0.1^{b}$ \\
\hline Clay (\%) & $30.3 \pm 3.5^{\mathrm{a}}$ & $28.5 \pm 2.3^{a}$ & $32.2 \pm 2.0^{\mathrm{a}}$ & $29.1 \pm 3.4^{\mathrm{a}}$ & $26.9 \pm 2.9^{a}$ \\
\hline Silt (\%) & $34.5 \pm 2.2^{\mathrm{a}}$ & $33.0 \pm 3.7^{\mathrm{a}}$ & $33.8 \pm 2.7^{a}$ & $31.5 \pm 0.5^{\mathrm{a}}$ & $28.0 \pm 0.7^{b}$ \\
\hline Sand (\%) & $35.2 \pm 0.4^{b}$ & $38.5 \pm 1.1^{\mathrm{ab}}$ & $34.0 \pm 0.2^{b}$ & $39.4 \pm 0.9^{a}$ & $45.1 \pm 1.8^{\mathrm{a}}$ \\
\hline
\end{tabular}

Note: Values are means \pm Standard Error (S.E.). Means followed by different lowercase letters within a row indicate significant differences among stand ages according to Tukey's Honest Significant Difference (HSD) test $(P<0.05)$.

\subsection{Field Sampling and Measurements}

On the basis of the DBH and height measurements in the sampling plots, we harvested six standard trees from different diameter classes in each stand for biomass measurements (30 trees in total). The aboveground portions of the standard trees were divided into 5-cm sections for measurement. We measured the fresh weights of stems, branches and foliage in situ. The belowground portions were obtained by total excavation of the standard trees, extending radially out from the trunk and downwards to bedrock until no more roots were visible. We measured the fresh weights of root collars, stump roots, thick roots (diameter $(D) \geq 2 \mathrm{~cm})$, small roots $(0.5 \leq D<2 \mathrm{~cm})$, and fine roots $(D<0.5 \mathrm{~cm})$ in situ. Samples (500 g) of each compartment in each standard tree were collected, and then oven-dried at $70{ }^{\circ} \mathrm{C}$ to a constant weight to calculate the ratio of fresh weight to dry biomass. We built regression models for the different compartments to evaluate tree biomass $(n=30)$, and the models can be obtained in our previous work [22].

Latex was collected three times a month from the onset of tapping in May 2009 and extended about 7 months. The latex production was recorded through weighing of the fresh material separately for all trees of each plot. The dry weight was measured after oven-drying representative subsamples of latex (six collecting bottles) at $70{ }^{\circ} \mathrm{C}$ to a constant weight. Meanwhile, monthly tapping times were also recorded. Then, a model $\left(y=-0.002 x^{2}+0.089 x+0.584 ; P<0.05\right)$ was fitted using annual yield $\left(\mathrm{y}, \mathrm{t} \mathrm{ha}^{-1} \mathrm{year}^{-1}\right)$ and stand age $(\mathrm{x})$. The total production during the whole tapping phase was calculated by accumulating consecutive annual yield. 
Litter, including leaves, twigs $(D<2 \mathrm{~cm})$, flowers / fruits, and miscellaneous litter compartments, were collected every month between January 2009 and December 2009 using 10 litter traps $(1 \times 1 \mathrm{~m})$ that were randomly distributed in each sampling plot. Litter samples were oven-dried at $70{ }^{\circ} \mathrm{C}$ to a constant weight to determine the ratio of fresh weight to dry biomass. Plant biomass in the shrub and herbaceous layers was negligible or practically missing due to regular removal by local farmers, except for their litter, and has thus not been investigated.

Three soil profiles in each plot were dug to a depth of $100 \mathrm{~cm}$, and the samples were taken from six depths $(0-10,10-20,20-40,40-60,60-80$ and $80-100 \mathrm{~cm})$ using a soil corer ( $5 \mathrm{~cm}$ inner diameter). Soil samples from the same depth in the same plot were mixed in equal volume proportions and air-dried at room temperature. Bulk density for each soil depth was determined by collecting samples from a stainless steel cylinder $\left(100 \mathrm{~cm}^{3}\right)$ and oven drying the soil core at $105{ }^{\circ} \mathrm{C}$ for constant weight. Bulk density was calculated by dividing the mass of oven-dried soil by the volume of the core. Three soil samples were taken from every depth.

For analysis of $C$ concentration, biomass samples were ground and passed through a $1 \mathrm{~mm}$ sieve. Mineral soil samples were sieved through a $0.149 \mathrm{~mm}$ sieve before chemical analysis. The $\mathrm{C}$ concentrations of tree, latex and soil samples were measured by a dry combustion method with a vario MAX CNS elemental analyzer (Elementar, Langenselbold, Germany). The tree, latex and litter $C$ stocks $\left(\mathrm{Mg} \mathrm{ha}^{-1}\right)$ were calculated by multiplying $\mathrm{C}$ concentration by dry biomass $\left(\mathrm{t} \mathrm{ha}{ }^{-1}\right)$. The tree NPP $\left(\mathrm{t} \mathrm{ha}^{-1}\right.$ year ${ }^{-1}$ ) was calculated by dividing total $C$ stock by the corresponding stand age. The latex and litter NPP was estimated by total collection amount during a year. The SOC stock $\left(\mathrm{Mg} \mathrm{ha}^{-1}\right)$ was calculated by multiplying $C$ concentration by bulk density and thickness of the soil layer with a correction for stone content.

\subsection{Statistical Analysis}

One-way ANOVA following Tukey's Honest Significant Difference (HSD) test was used to test the differences in biomass production, and $\mathrm{C}$ stocks in different compartments affected by stand age. A quadratic polynomial regression was applied to check the relationship between $\mathrm{C}$ stocks in different compartments and stand age. The software SPSS 13.0 (SPSS Inc., Chicago, IL, USA) was employed for all statistical analyses at a significance level of 0.05 .

\section{Results}

\subsection{Biomass C Concentration and Stock}

The $\mathrm{C}$ concentration varied substantially among different compartments of rubber trees (Figure 1). The $C$ concentration of all tree compartments in the 19-year-old stand was lower in range than in other stands (although not significantly) (Figure 1a). Across all age groups, foliage had the highest $\mathrm{C}$ concentration $(51.2 \pm 0.4 \%)$, whereas roots had the lowest value ( $46.7 \pm 0.4 \%)$. The latex $C$ concentration $(84.7 \pm 0.8 \%)$ was not affected by stand age (Figure $1 \mathrm{~b})$. A significant difference in litter $\mathrm{C}$ concentration was only observed between the 7- and 13-year-old stands (Figure 1c). For root compartments, average $\mathrm{C}$ concentration declined in the following order: root collar $>$ stump root $>$ thick root $>$ small root $>$ fine root (Figure 1d).

The total biomass (TB) including above- (AGB) and belowground (BGB) and latex yield increased with stand age (Table 2). AGB was the largest compartment of $C$ storage in biomass $(68.3 \pm 1.0 \%)$, followed by latex yield $(17.3 \pm 2.7 \%)$ and BGB $(14.3 \pm 2.0 \%)$ across all age groups. A quadratic regression analysis showed that the proportion of aboveground biomass $C$ (AGBC)/total biomass $C$ (TBC) was not related to stand age $\left(R^{2}=0.10, P=0.35\right)$, but a high correlation in latex $\mathrm{C} / \mathrm{TBC}\left(R^{2}=0.62\right.$, $P=0.003)$, belowground biomass C (BGBC) $/ \mathrm{TBC}\left(R^{2}=0.93, P<0.001\right)$, and BGBC $/ \mathrm{AGBC}\left(R^{2}=0.97\right.$, $P<0.001)$ could be observed, respectively. 


\subsection{Biomass NPP and Associated C Sequestration}

The biomass NPP and associated C sequestration of various compartments increased first and then decreased with stand age, with the higher values between the 19- and 25-year-old stands, except $\mathrm{NPP}_{\text {litter }}$ (Table 3). Across all age groups, more than $75 \%$ of $\mathrm{C}$ was sequestrated in aboveground tree and litter. Moreover, around 18\% of NPP was attributed to latex yield, whereas a smaller percentage of NPP was allocated to root. NPP total, whether including latex $\mathrm{C}$ or not, showed a close quadratic relationship with stand age $\left(R^{2}=0.80, P<0.001\right.$; or $\left.R^{2}=0.79, P<0.001\right)$.

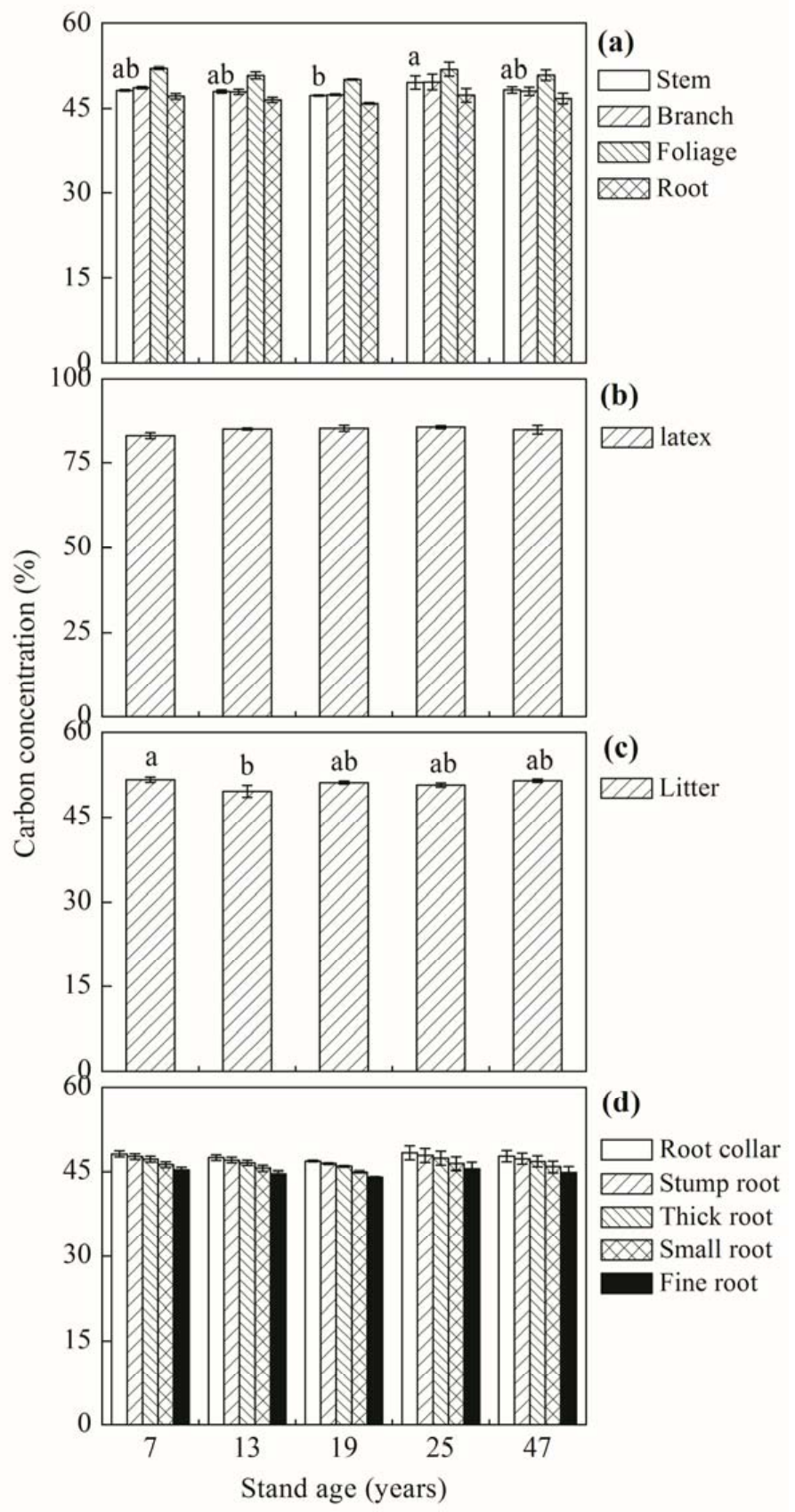

Figure 1. Carbon concentrations (as \% of biomass) in different biomass compartments: tree (a), latex (b), litter (c) and specific root (d), of the 7-, 13-, 19-, 25- and 47-year-old rubber plantations at Xishuangbanna, Yunnan Province, China. Presence of different lowercase letters indicates significant differences among means of stand ages according to Tukey's HSD test $(P<0.05)$. Vertical bars show \pm S.E. 
Table 2. Above- and belowground biomass and latex yield ( $\mathrm{tha}^{-1}$ ) and carbon stock (in brackets $\mathrm{Mg} \mathrm{C}^{-1}$ ) in different compartments of the 7-, 13-, 19-, 25- and 47-year-old rubber plantations at Xishuangbanna, Yunnan Province, China.

\begin{tabular}{|c|c|c|c|c|c|}
\hline Biomass Fraction & 7-year-old & 13-year-old & 19-year-old & 25-year-old & 47-year-old \\
\hline \multicolumn{6}{|l|}{ Aboveground tree } \\
\hline Stem & $12.86 \pm 1.57(6.20)^{c}$ & $38.66 \pm 1.88(18.56)^{c}$ & $92.17 \pm 6.77(43.57)^{b}$ & $106.56 \pm 9.52(52.88)^{b}$ & $169.50 \pm 16.19(81.84)^{a}$ \\
\hline Branch & $3.63 \pm 0.44(1.77)^{\mathrm{c}}$ & $10.74 \pm 0.53(5.15)^{\mathrm{c}}$ & $25.29 \pm 1.86(12.00)^{b}$ & $29.15 \pm 2.60(14.48)^{b}$ & $45.54 \pm 4.32(21.87)^{\mathrm{a}}$ \\
\hline Foliage & $0.75 \pm 0.09(0.39)^{\mathrm{c}}$ & $1.87 \pm 0.10(0.95)^{\mathrm{c}}$ & $3.88 \pm 0.30(1.94)^{b}$ & $4.32 \pm 0.37(2.24) \mathrm{ab}$ & $5.62 \pm 0.51(2.86)^{\mathrm{a}}$ \\
\hline \multicolumn{6}{|l|}{ Litter } \\
\hline Leaf & $2.50 \pm 0.09(1.29)^{b}$ & $3.82 \pm 0.20(1.90)^{\mathrm{a}}$ & $4.24 \pm 0.30(2.17)^{\mathrm{a}}$ & $3.77 \pm 0.06(1.92)^{\mathrm{a}}$ & $4.12 \pm 0.05(2.12)^{\mathrm{a}}$ \\
\hline Twig & $0.02 \pm 0.00(0.01)^{\mathrm{c}}$ & $0.40 \pm 0.08(0.20)^{\mathrm{b}}$ & $0.59 \pm 0.14(0.30)^{a b}$ & $0.82 \pm 0.02(0.42)^{\mathrm{a}}$ & $0.40 \pm 0.04(0.21)^{b}$ \\
\hline Flower/fruit & $0.10 \pm 0.01(0.06)^{c}$ & $0.35 \pm 0.07(0.18)^{b}$ & $0.26 \pm 0.07(0.14)^{b}$ & $0.92 \pm 0.01(0.47)^{a}$ & $0.76 \pm 0.10(0.39)^{a}$ \\
\hline Miscellaneous litter & $0.12 \pm 0.01(0.06)^{c}$ & $0.15 \pm 0.01(0.08)^{c}$ & $0.16 \pm 0.01(0.08)^{b c}$ & $0.23 \pm 0.01(0.12)^{b}$ & $0.42 \pm 0.03(0.22)^{a}$ \\
\hline Total litter & $2.74 \pm 0.12(1.42)^{b}$ & $4.72 \pm 0.36(2.35)^{\mathrm{a}}$ & $5.25 \pm 0.53(2.69)^{\mathrm{a}}$ & $5.74 \pm 0.08(2.93)^{\mathrm{a}}$ & $5.70 \pm 0.21(2.94)^{\mathrm{a}}$ \\
\hline Total AGB & $19.98 \pm 2.11(9.78)^{\mathrm{c}}$ & $55.99 \pm 2.87(27.01)^{\mathrm{c}}$ & $126.59 \pm 9.46(60.20)^{b}$ & $145.77 \pm 12.57(72.53)^{b}$ & $226.36 \pm 21.23(109.51)^{a}$ \\
\hline \multicolumn{6}{|l|}{ Root } \\
\hline Root collar & $2.41 \pm 0.26(1.16)^{c}$ & $6.13 \pm 0.38(2.91)^{b}$ & $7.21 \pm 0.61(3.38)^{a b}$ & $9.29 \pm 0.79(4.49)^{\mathrm{a}}$ & $9.59 \pm 0.83(4.57)^{\mathrm{a}}$ \\
\hline Stump root & $2.34 \pm 0.25(1.11)^{c}$ & $4.35 \pm 0.27(2.04)^{b}$ & $6.20 \pm 0.52(2.87)^{a}$ & $4.59 \pm 0.39(2.19)^{b}$ & $4.42 \pm 0.38(2.09)^{b}$ \\
\hline Thick root & $0.46 \pm 0.05(0.22)^{c}$ & $1.32 \pm 0.08(0.62)^{c}$ & $5.15 \pm 0.43(2.37)^{b}$ & $9.41 \pm 0.80(4.45)^{\mathrm{a}}$ & $8.17 \pm 0.71(3.82)^{a}$ \\
\hline Small root & $0.44 \pm 0.05(0.21)^{c}$ & $0.99 \pm 0.06(0.45)^{c}$ & $4.43 \pm 0.37(1.99)^{a}$ & $2.54 \pm 0.22(1.18)^{b}$ & $5.58 \pm 0.48(2.56)^{a}$ \\
\hline Fine root & $0.47 \pm 0.05(0.21)^{\mathrm{c}}$ & $0.75 \pm 0.05(0.33)^{c}$ & $2.46 \pm 0.21(1.08)^{b}$ & $1.69 \pm 0.14(0.77)^{b}$ & $3.42 \pm 0.30(1.54)^{\mathrm{a}}$ \\
\hline Total BGB & $6.12 \pm 0.66(2.91)^{c}$ & $13.53 \pm 0.84(6.35)^{b}$ & $25.45 \pm 2.14(11.69)^{\mathrm{a}}$ & $27.52 \pm 2.34(13.08)^{a}$ & $31.19 \pm 2.69(14.58)^{\mathrm{a}}$ \\
\hline $\mathrm{BGB} / \mathrm{AGB}$ & $0.31 \pm 0.00(0.30)^{a}$ & $0.24 \pm 0.00(0.24)^{b}$ & $0.20 \pm 0.00(0.19)^{c}$ & $0.19 \pm 0.00(0.18)^{\mathrm{d}}$ & $0.14 \pm 0.00(0.13)^{\mathrm{e}}$ \\
\hline Latex & $1.10 \pm 0.00(0.91)^{\mathrm{e}}$ & $8.74 \pm 0.10(7.43)^{d}$ & $17.51 \pm 0.28(14.92)^{\mathrm{c}}$ & $26.47 \pm 0.50(22.66)^{b}$ & $46.15 \pm 0.84(38.63)^{\mathrm{a}}$ \\
\hline TB & $27.20 \pm 2.88(13.61)^{c}$ & $78.26 \pm 3.72(40.79)^{c}$ & $169.55 \pm 11.62(86.82)^{b}$ & $199.76 \pm 14.93(108.27)^{b}$ & $303.70 \pm 23.71(162.72)^{a}$ \\
\hline
\end{tabular}

Note: Values are means \pm S.E. Means followed by different lowercase letters in the same row indicate significant differences among stand ages according to Tukey's HSD test $(P<0.05)$ AGB: aboveground biomass; BGB: belowground biomass; TB: total biomass. 
Table 3. Net primary productivity (NPP) ( $\mathrm{t} \mathrm{ha}^{-1}$ year $^{-1}$ ) and carbon stock (in brackets $\mathrm{Mg} \mathrm{C}$ ha $^{-1}$ year ${ }^{-1}$ ) in different compartments of the 7-, 13-, 19-, 25- and 47-year-old rubber plantations at Xishuangbanna, Yunnan Province, China.

\begin{tabular}{|c|c|c|c|c|c|}
\hline NPP Fraction & 7-year-old & 13-year-old & 19-year-old & 25-year-old & 47-year-old \\
\hline $\mathrm{NPP}_{\text {aboveground tree }}$ & $2.46 \pm 0.30(1.19)^{\mathrm{C}}$ & $3.94 \pm 0.19(1.90)^{b, c}$ & $6.39 \pm 0.47(3.03)^{\mathrm{a}}$ & $5.60 \pm 0.50(2.78)^{a, b}$ & $4.69 \pm 0.45(2.27)^{\mathrm{a}, \mathrm{b}}$ \\
\hline $\mathrm{NPP}_{\text {litter }}$ & $2.74 \pm 0.12(1.42)^{b}$ & $4.72 \pm 0.36(2.35)^{\mathrm{a}}$ & $5.25 \pm 0.53(2.69)^{\mathrm{a}}$ & $5.74 \pm 0.08(2.93)^{\mathrm{a}}$ & $5.70 \pm 0.21(2.94)^{\mathrm{a}}$ \\
\hline $\mathrm{NPP}_{\text {root }}$ & $0.87 \pm 0.09(0.42)^{b, c}$ & $1.04 \pm 0.06(0.49)^{\mathrm{a}, \mathrm{b}}$ & $1.33 \pm 0.11(0.62)^{a}$ & $1.10 \pm 0.09(0.52)^{a, b}$ & $0.66 \pm 0.05(0.31)^{\mathrm{c}}$ \\
\hline $\mathrm{NPP}_{\text {latex }}$ & $1.10 \pm 0.00(0.91)^{\mathrm{c}}$ & $1.25 \pm 0.01(1.06)^{b}$ & $1.35 \pm 0.02(1.14)^{a}$ & $1.39 \pm 0.03(1.19)^{\mathrm{a}}$ & $1.12 \pm 0.02(0.94)^{\mathrm{c}}$ \\
\hline $\mathrm{NPP}_{\text {total }}$ & $7.17 \pm 0.51(3.94)^{b}$ & $10.95 \pm 0.62(5.79)^{\mathrm{a}}$ & $14.32 \pm 1.11(7.48)^{a}$ & $13.83 \pm 0.67(7.42)^{\mathrm{a}}$ & $12.18 \pm 0.71(6.46)^{a}$ \\
\hline
\end{tabular}

Note: Values are means \pm S.E. Means followed by different lowercase letters in the same row indicate significant differences among stand ages according to Tukey's HSD test $(P<0.05)$. 


\subsection{SOC Concentration and Stock}

The SOC concentration decreased from $1.2 \%$ to $1.0 \%$ in $100 \mathrm{~cm}$ depth with stand age. Regardless of stand age, the average SOC concentration declined significantly with depth, ranging from $1.6 \%$ at $0-20 \mathrm{~cm}$ to $0.6 \%$ at $80-100 \mathrm{~cm}$. By contrast, bulk density increased from $1.32 \mathrm{~g} \mathrm{~cm}^{-3}$ to $1.41 \mathrm{~g} \mathrm{~cm}^{-3}$ with stand age. Irrespective of stand age, the average bulk density increased with depth, ranging from $1.31 \mathrm{~g} \mathrm{~cm}^{-3}$ at $0-20 \mathrm{~cm}$ to $1.39 \mathrm{~g} \mathrm{~cm}^{-3}$ at $80-100 \mathrm{~cm}$.

The SOC stock in $100 \mathrm{~cm}$ depth slightly decreased from $146.0 \mathrm{Mg} \mathrm{ha}^{-1}$ in the 7-year-old stand to $129.1 \mathrm{Mg} \mathrm{ha}^{-1}$ in the 47 -year-old stand (Figure 2). Across all age groups, SOC stock decreased rapidly with depth, ranging from $41.9 \mathrm{Mg} \mathrm{ha}^{-1}$ at $0-20 \mathrm{~cm}$ to $17.5 \mathrm{Mg} \mathrm{ha}^{-1}$ at $80-100 \mathrm{~cm}$. With the exception of the 7-year-old stand, more than $52.5 \%$ of SOC was accumulated within the $40 \mathrm{~cm}$ depth for each stand.

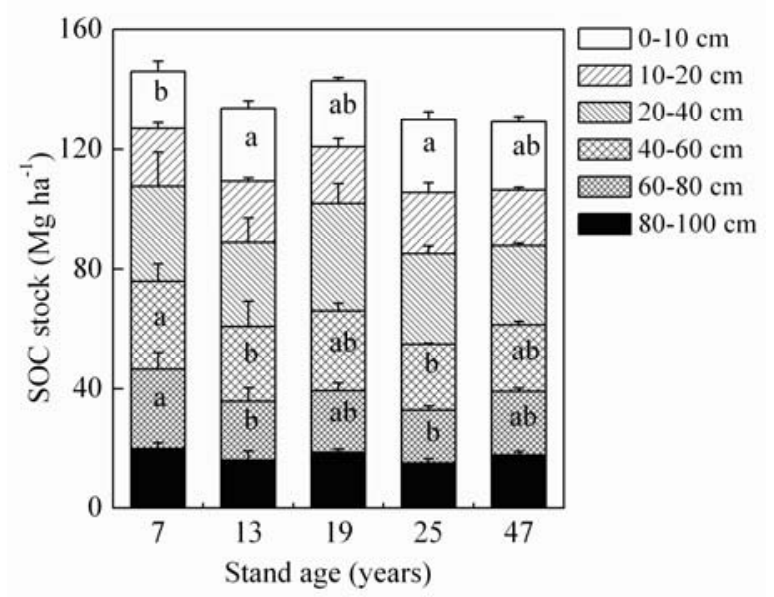

Figure 2. Soil organic carbon (SOC) stock in different soil layers of the 7-, 13-, 19-, 25- and 47-year-old rubber plantations at Xishuangbanna, Yunnan Province, China. Presence of different lowercase letters across a respective soil layer indicates significant differences among means of stand ages according to Tukey's HSD test $(P<0.05)$. Vertical bars show \pm S.E.

\subsection{Ecosystem C Stock and Its Relationship between Main Compartments}

The total ecosystem C stock (TEC) increased with stand age, ranging from $159.6 \mathrm{Mg} \mathrm{ha}^{-1}$ in the 7-year-old stand to $291.9 \mathrm{Mg} \mathrm{ha}^{-1}$ in the 47 -year-old stand. The contribution from TBC to TEC increased from $8.6 \%$ for the 7 -year-old stand to $55.1 \%$ for the 47 -year-old stand; therein, latex C contributed $0.6-13.4 \%$ to TEC with stand age (Figure 3). Most of TEC was occupied by SOC rather than TBC. Indeed, $91.4 \%$ of TEC in the 7-year-old stand was sequestrated in $100 \mathrm{~cm}$ soil depth. This proportion decreased significantly with stand age, and fell to $44.9 \%$ in the 47 -year-old stand. SOC stock was not correlated with age classes $(P=0.30)$ (Table 4$)$.

A quadratic regression analysis showed that $C$ stored in main biomass compartments was highly correlated with stand age $(P<0.001)$, whereas SOC stock was not correlated with age classes $(P=0.30)$. The TEC, whether excluding latex $C$ or not, also exhibited a close correlation with stand age $(P<0.001)$. The quadratic model predicted that the maximum TEC will occur at around 54 years, which is much larger than comprehensive prediction (38 years) using previous data excluding latex $\mathrm{C}$. 


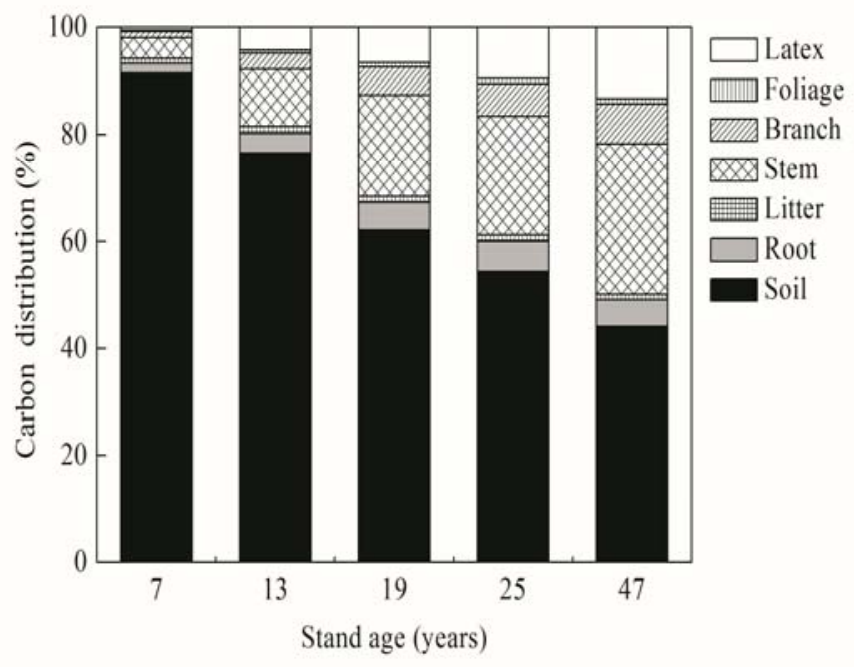

Figure 3. Percentage distribution of carbon stock in various compartments of rubber plantation ecosystem of five different ages.

Table 4. The relationship between carbon stored in different compartments of rubber plantation ecosystem and stand age.

\begin{tabular}{cccccc}
\hline Compartments & Regression Equation & $\boldsymbol{R}^{\mathbf{2}}$ & SEE & $\boldsymbol{F}$-Value & $\boldsymbol{P}$ \\
\hline Aboveground tree & $\mathrm{y}=-0.049 \mathrm{x}^{2}+5.150 \mathrm{x}-27.724$ & 0.802 & 19.028 & 24.398 & $<0.001$ \\
Litter & $\mathrm{y}=-0.002 \mathrm{x}^{2}+0.154 \mathrm{x}+0.547$ & 0.841 & 0.271 & 31.703 & $<0.001$ \\
Root & $\mathrm{y}=-0.014 \mathrm{x}^{2}+1.034 \mathrm{x}-3.934$ & 0.711 & 3.105 & 14.746 & $<0.001$ \\
Latex & $\mathrm{y}=-0.011 \mathrm{x}^{2}+1.533 \mathrm{x}-9.878$ & 0.995 & 1.090 & 1076.113 & $<0.001$ \\
Soil & $\mathrm{y}=0.012 \mathrm{x}^{2}-1.015 \mathrm{x}+150.766$ & 0.181 & 12.590 & 1.329 & 0.300 \\
$\begin{array}{c}\text { Total excluding latex C } \\
\text { (our study) }\end{array}$ & $\mathrm{y}=-0.053 \mathrm{x}^{2}+5.323 \mathrm{x}+119.655$ & 0.774 & 20.412 & 20.529 & $<0.001$ \\
$\begin{array}{c}\text { Total excluding latex C } \\
\text { (comprehensive) * }\end{array}$ & $\mathrm{y}=-0.098 \mathrm{x}^{2}+7.508 \mathrm{x}+104.044$ & 0.328 & 58.128 & 6.349 & 0.006 \\
$\begin{array}{c}\text { Total including latex C } \\
\text { (our study) }\end{array}$ & $\mathrm{y}=-0.063 \mathrm{x}^{2}+6.856 \mathrm{x}+109.78$ & 0.869 & 20.343 & 39.612 & $<0.001$ \\
\hline
\end{tabular}

* Data of total ecosystem C stock (comprehensive) were collected from previous studies irrespective of management practices, soil texture and environmental conditions [17-21,23-34]. Note: a, b, $R^{2}$, SEE denotes slope, intercept, coefficient of determination and model's standard error, respectively.

\section{Discussion}

\subsection{Biomass C Accumulation}

Accurate estimates of $C$ stocks in different development stages of a plantation are important for assessing their role in regional and global $\mathrm{C}$ management. The $\mathrm{C}$ concentration varies with type of tree compartments (stems, branches, foliage and roots), type of wood (normal, tension or compression), soil conditions, geographical location, and climate [35]. Thus, the compartment-specific $\mathrm{C}$ concentration is often used when converting biomass to $\mathrm{C}$ stock instead of a standard factor of $50 \%$ [36]. The average $C$ concentration of rubber tree (48.4\%) (Figure 1) was higher than that of taller plants (43.6\%) [37]. The use of 50\% therefore could overestimate biomass $C$ stock by as much as $4 \%$ in this region. Moreover, the lowest $C$ concentration in the 19-year-old tree is attributed to a highest increment rate, so maybe the fast growth rate will result in less dense biomass. We suggest that a general C concentration of $48 \%$ can be applied as an alternative to empirical assessments of site-specific values.

The TBC including $A G B C, B G B C$, and latex $C$ of rubber plantation increased and showed a quadratic trend with stand age (Table 2). The BGBC/AGBC ratio decreased with stand age, which 
is different from another study reporting larger $C$ accumulation in roots over a long time period

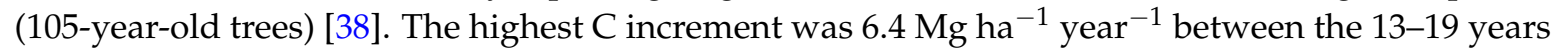
stands (Table 2), which is associated with the fast growth rates. Rubber plantations grown in potentially dissimilar conditions in Brazil $[18,20]$ and Asia $[17,19,23]$ have revealed comparable C increments, varying from 1.4 to $6.7 \mathrm{Mg} \mathrm{ha}^{-1}$ year $^{-1}$, with the highest value occurring between the 10-20 years stands. Moreover, the largest TBC in the 47-year-old stand was higher than the value of $110.9 \mathrm{Mg} \mathrm{ha}^{-1}$ measured for tropical forest in China [39]. These comparisons indicate that rubber plantation can serve as an effective $C$ sink by a rapid rate of biomass $C$ accumulation in the early stages, although the rate will slow down with stand age.

The $\mathrm{C}$ stock of fine roots was age-dependent (Table 2). The majority of fine root $\mathrm{C}$ was located in the upper $40 \mathrm{~cm}$ soil depth (data not shown) due to abundant water and nutrients, which is consistent with recent findings in other tree species [40,41]. Furthermore, litter C stock increased with stand age. This trend is in line with some chronosequence studies of broad-leaved plantations [42,43], but not with some others [13,44], indicating large between-stand variability. The discrepancies result from input and decomposition rates of litter that are highly susceptible to disturbances and spatial variation [36,45]. We also found that the $C$ stock of litter in each stand was greater than that of foliage, suggesting that litter should be considered an essential component in TBC assessment.

Our estimate of $\mathrm{NPP}_{\text {total }}$ for rubber plantation, whether excluding latex $\mathrm{C}$ or not, had a close quadratic relationship with stand age. The average $\mathrm{NPP}_{\text {total }}$ amounting to $6.2 \mathrm{Mg} \mathrm{ha}^{-1}$ year $^{-1}$ during the 47 years was a little lower than the estimated rates $\left(\sim 7.8 \mathrm{Mg} \mathrm{ha}^{-1}\right.$ year $\left.^{-1}\right)$ reported in previous studies [10,46]. This discrepancy is mainly attributed to single age measurement (e.g., 16- or 33-year-old) in their studies. However, a rubber plantation can be considered to have a considerable $\mathrm{C}$ sequestration capacity, although its estimated NPP is lower than the global NPP of $10.9 \mathrm{Mg} \mathrm{ha}^{-1}$ year $^{-1}$ measured for tropical forests [47]. Moreover, latex C was more prominent in its contribution to NPP relative to roots (Table 3), which is consistent with the estimate by Kotowska et al. [10], who reported about $20.8-31.3 \%$ of NPP was allocated to latex, while a smaller percentage was attributed to leaf and root in rubber monoculture of Indonesia. Eventually, latex $\mathrm{C}$ will be stored in industrial products, such as tires. It is worth noting that latex yield measured in a given year or estimated from our model does not accurately reflect the rubber productivity of the whole economic lifespan. Therefore, a continuous monitoring in latex yield is necessary to estimate rubber plantation $\mathrm{NPP}_{\text {total }}$ accurately.

\subsection{Soil C Stock}

Although soil $\mathrm{C}$ generally is expected to decrease due to soil disturbance and aeration in the early decades after plantation establishment $[38,44]$, some studies suggest that SOC stock is neutral, i.e., neither increases nor decreases with stand age $[1,16,48]$. This phenomenon may be ascribed to numerous factors, such as soil properties, tree species, pre-planting disturbance, and site management, all of which may individually or jointly overshadow the effect of stand age on SOC stock $[13,36]$. We found no significant correlation between SOC stock and stand age, indicating fast organic C turnover in rubber soils. However, about $22.3 \mathrm{Mg} \mathrm{ha}^{-1} \mathrm{SOC}$ stock has been lost over a period of 47 years compared with its amount before rubber establishment (151.4 $\left.\mathrm{Mg} \mathrm{ha}^{-1}\right)$. Similarly, de Blécourt et al. [9] found that forest-to-rubber transition resulted in SOC stock loss of $120 \mathrm{~cm}\left(37.4 \mathrm{Mg} \mathrm{ha}^{-1}\right)$ over a period of 46 years, which was equal to $19.3 \%$ of the initial SOC stock in the secondary forests. By contrast, Maggiotto et al. [20] found a small, but significant, increase in SOC stock (12.4 Mg ha ${ }^{-1}$ ) over 11 years of rubber plantation. Over the long run, however, SOC stock trajectory with stand age will tend to be relatively stable and remains an essential part of the $C$ budget of the overall plantation ecosystem.

In addition, SOC in the topsoil did not increase with stand age, whereas its stock estimated using a modelling method showed a positive trend [48]. Approximately $48.0-57.8 \%$ of SOC was found in the top $40 \mathrm{~cm}$ soil in all stands (Figure 2), despite the topsoil being vulnerable to human disturbance and natural erosion [16]. Thus, focus on the vertical variability of SOC stock, and protection of the topsoil from loss is essential for $C$ sequestration [14]. The average SOC stock of $136.0 \mathrm{Mg} \mathrm{ha}^{-1}$ in $100 \mathrm{~cm}$ 
depth (Figure 2) was similar to the mean value of $146.2 \mathrm{Mg} \mathrm{ha}^{-1}$ obtained from different-aged rubber plantations [18,23], but higher than that $\left(89.5-96.9 \mathrm{Mg} \mathrm{ha}^{-1}\right)$ in Thailand [19] and Hainan Island [29]. These results indicate that SOC stock is largely determined by the site-specific C concentration, and the soil with the low initial concentration will easily increase $C$ sink following transition to rubber, and vice versa [8]. Moreover, SOC stock that we observed was higher than the $116.5 \mathrm{Mg} \mathrm{ha}^{-1}$ measured for tropical forest soil in China [39]. Thus, we speculate that organic matter decomposition and subsequent accumulation in soil $\mathrm{C}$ in our study region happens faster than that in the whole Chinese tropical forest due to precipitation surplus or intensive management.

\subsection{Ecosystem C Stock}

The TEC increased by nearly $82.9 \%$ with stand age and would reach maximal value in a 54-year-old stand according to quadratic model including latex $C$, indicating a considerable $C$ sequestration potential in rubber plantation. By contrast, Nizami et al. [21] predicted rubber plantation to be a smaller $\mathrm{C}$ sink (186.7 $\mathrm{Mg} \mathrm{ha}^{-1}$ ) in a 40-year rotation using the $\mathrm{CO}_{2}$ FIX Model. Another important finding was that SOC stock was relatively stable over age sequence, whereas its contribution to TEC decreased rapidly with stand age (Figure 3), similar to the results from Pinus strobus [36] and Cyclobalanopsis glauca [41] plantations. This trend did not occur in some other plantations due to the differences in the rates of biomass and soil $\mathrm{C}$ accumulation among tree species during stand development [40,44]. Uri et al. [13] found that AGBC will ultimately surpass SOC stock of the older stand. We suggest that when considering a maximal life expectancy, biomass including latex yield will become the major $C$ stock of rubber plantation. Therefore, further evidence for ecosystem $C$ pool dependence on stand age will be required, in particular from studies with a very long time perspective (>50 years).

\subsection{The Implications of Rubber Plantation on C Sequestration}

Although forest-to-rubber transition can increase farmer income in the short term, more attention should be paid to the implications for $C$ sequestration of the transition, especially transitions with baselines in the two main forest types: degraded and natural (maybe even undisturbed) forests. Firstly, large areas of degraded forest lands with low $C$ stocks could benefit from the establishment of rubber plantation [5]. For example, biomass $C$ in five different-aged rubber plantations (Table 2) was always higher than that in degraded forest in the same region as reported by Tang et al. [49], indicating a rapid biomass accumulation rate in rubber plantation. Secondly, the consequence of converting natural forest with high $C$ stock, old-growth forest in particular, to rubber has been shown to result in large $C$ debt [9], because rubber plantation $C$ payback time is about 40 years [21,31]. Under these two land-use scenarios, biomass $C$ has been predicted to increase by about $11.8 \mathrm{Tg}$ or drop by about $4.13 \mathrm{Tg}$ in Xishuangbanna during the next 20 years [7]. Moreover, rubber plantations could induce increased $\mathrm{C}$ sequestration at around 22 years of growth, according to a quadratic regression model (Table 4), because the stock at that time is projected to exceed the average TEC (230.4 Mg ha $\left.{ }^{-1}\right)$ for Chinese tropical forest. As a result, there is no doubt that rubber plantation can be considered as alternative land use without affecting forest ecosystem $C$ storage.

There are big drawbacks, however, to the large-scale rubber monoculture in the form of reduction in biodiversity, loss of soil and water, and an increase in vulnerability to diseases and pests [5]. For example, as little as $129.4 \mathrm{Mg} \mathrm{C}^{-1}$ in soil is left once a rubber plantation is harvested for rotation (40 years). By contrast, rubber agroforestry systems are found to be environmentally-friendly due to their diversity and complexity. For example, leguminous cover crops planted between rubber trees can substantially increase $C$ stock in addition to improving soil fertility [50]. Further studies on ecosystem $C$ stock of rubber plantations should include not only potential ecological issues associated with monocultures but also comparisons to mixed agroforestry systems in general. 


\section{Conclusions}

In a chronosequence of rubber plantations in tropical China, the TBC and $\mathrm{NPP}_{\text {total }}$, whether including latex $\mathrm{C}$ or not, had a close quadratic relationship with stand age. Regardless of stand age, around $68 \%$ of the $\mathrm{C}$ was stored in aboveground biomass, and $\mathrm{NPP}_{\text {latex }}$ contributed to approximately $18 \%$ of $C$ sequestration. However, SOC stock in the $100 \mathrm{~cm}$ depth was age-independent, and decreased with soil depth for each stand. The TEC across stands averaged 159.6, 174.4, 229.6, 238.1 and $291.9 \mathrm{Mg} \mathrm{ha}^{-1}$, respectively, of which more than $45 \%$ was stored in the soil. When considering a maximal life expectancy of rubber trees, the $C$ accumulated in biomass would exceed soil over age sequence. Regression analysis showed that rubber plantations have a potential role in improving the regional $\mathrm{C}$ budget in the long term (achieving maximum at about 54 years), and thus they can be considered as alternative land use without affecting forest ecosystem $C$ storage. We also suggest that further research on ecosystem $C$ pool dependence on stand age in rubber agroforestry systems is needed to fully achieve a "win-win" balance between environmental and economic benefits in tropical China.

Acknowledgments: We thank Yun Lu and Defu Chen for helping with field work and the members in the Biogeochemistry Laboratory of the Xishuangbanna Tropical Botanical Garden for $\mathrm{C}$ analysis. This study was supported by the National Natural Science Foundation of China (31600507), the Chinese Academy of Sciences (CAS) "Light of West China" Program, the Natural Science Foundation of Yunnan Province (2016FA047), and the key program of CAS (KFZD-SW-312).

Author Contributions: J.T. and X.L. conceived and designed the experiments; J.P. performed the experiments; C.L. and J.P. analyzed the data; M.R.J. contributed reagents/materials/analysis tools; C.L. wrote the paper.

Conflicts of Interest: The authors declare no conflict of interest.

\section{References}

1. Cheng, J.Z.; Lee, X.Q.; Theng, B.K.G.; Zhang, L.K.; Fang, B.; Li, F.S. Biomass accumulation and carbon sequestration in an age-sequence of Zanthoxylum bungeanum plantations under the Grain for Green Program in karst regions, Guizhou province. Agric. For. Meteorol. 2015, 203, 88-95. [CrossRef]

2. Nogueira, E.M.; Yanai, A.M.; Fonseca, F.O.; Fearnside, P.M. Carbon stock loss from deforestation through 2013 in Brazilian Amazonia. Glob. Chang. Biol. 2015, 21, 1271-1292. [CrossRef] [PubMed]

3. Pan, Y.D.; Birdsey, R.A.; Fang, J.Y.; Houghton, R.; Kauppi, P.E.; Kurz, W.A.; Phillips, O.L.; Shvidenko, A.; Lewis, S.L.; Canadell, J.G.; et al. A large and persistent carbon sink in the world's forests. Science 2011, 333, 988-993. [CrossRef] [PubMed]

4. Hansen, M.C.; Potapov, P.V.; Moore, R.; Hancher, M.; Turubanova, S.A.; Tyukavina, A.; Thau, D.; Stehman, S.V.; Goetz, S.J.; Loveland, T.R. High-resolution global maps of 21st-century forest cover change. Science 2013, 342, 850-853. [CrossRef] [PubMed]

5. Fox, J.; Castella, J.C.; Ziegler, A.D.; Westley, S.B. Rubber plantations expand in mountainous Southeast Asia: What are the consequences for the environment? AsiaPacific Issues 2014, 114, 1-8.

6. Zhang, L.; Kono, Y.; Kobayashi, S.; Hu, H.B.; Zhou, R.; Qin, Y. The expansion of smallholder rubber farming in Xishuangbanna, China: A case study of two Dai villages. Land Use Policy 2015, 42, 628-634. [CrossRef]

7. Li, H.M.; Ma, Y.X.; Aide, T.M.; Liu, W.J. Past, present and future land-use in Xishuangbanna, China and the implications for carbon dynamics. For. Ecol. Manag. 2008, 255, 16-22. [CrossRef]

8. Van Straaten, O.; Corre, M.D.; Wolf, K.; Tchienkoua, M.; Cuellar, E.; Matthews, R.B.; Veldkamp, E. Conversion of lowland tropical forests to tree cash crop plantations loses up to one-half of stored soil organic carbon. Proc. Natl. Acad. Sci. USA 2015, 112, 9956-9960. [CrossRef] [PubMed]

9. De Blécourt, M.; Brumme, R.; Xu, J.C.; Corre, M.D.; Veldkamp, E. Soil carbon stocks decrease following conversion of secondary forests to rubber (Hevea brasiliensis) plantations. PLoS ONE 2013, 8, e69357. [CrossRef] [PubMed]

10. Kotowska, M.M.; Leuschner, C.; Triadiati, T.; Meriem, S.; Hertel, D. Quantifying above- and belowground biomass carbon loss with forest conversion in tropical lowlands of Sumatra (Indonesia). Glob. Chang. Biol. 2015, 21, 3620-3634. [CrossRef] [PubMed] 
11. De Blécourt, M.; Hänsel, V.M.; Brumme, R.; Corre, M.D.; Veldkamp, E. Soil redistribution by terracing alleviates soil organic carbon losses caused by forest conversion to rubber plantation. For. Ecol. Manag. 2014, 313, 26-33. [CrossRef]

12. Kobayashi, N.; Kumagai, T.O.; Miyazawa, Y.; Matsumoto, K.; Tateishi, M.; Lim, T.K.; Mudd, R.G.; Ziegler, A.D.; Giambelluca, T.W.; Yin, S. Transpiration characteristics of a rubber plantation in central Cambodia. Tree Physiol. 2014, 34, 285-301. [CrossRef] [PubMed]

13. Uri, V.; Varik, M.; Aosaar, J.; Kanal, A.; Kukumägi, M.; Lõhmus, K. Biomass production and carbon sequestration in a fertile silver birch (Betula pendula Roth) forest chronosequence. For. Ecol. Manag. 2012, 267, 117-126. [CrossRef]

14. Li, T.J.; Ren, B.W.; Wang, D.H.; Liu, G.B. Spatial variation in the storages and age-related dynamics of forest carbon sequestration in different climate zones-evidence from Black Locust plantations on the Loess Plateau of China. PLoS ONE 2015, 10, e0121862. [CrossRef] [PubMed]

15. Yang, Y.H.; Luo, Y.Q.; Finzi, A.C. Carbon and nitrogen dynamics during forest stand development: A global synthesis. New Phytol. 2011, 190, 977-989. [CrossRef] [PubMed]

16. Khasanah, N.; van Noordwijk, M.; Ningsih, H.; Rahayu, S. Carbon neutral? No change in mineral soil carbon stock under oil palm plantations derived from forest or non-forest in Indonesia. Agric. Ecosyst. Environ. 2015, 211, 195-206. [CrossRef]

17. Dey, S.K. A preliminary estimation of carbon stock sequestrated through rubber (Hevea brasiliensis) plantation in north eastern region of India. Indian For. 2005, 131, 1429-1436.

18. Wauters, J.; Coudert, S.; Grallien, E.; Jonard, M.; Ponette, Q. Carbon stock in rubber tree plantations in Western Ghana and Mato Grosso (Brazil). For. Ecol. Manag. 2008, 255, 2347-2361. [CrossRef]

19. Saengruksawong, C.; Khamyong, S.; Anongrak, N.; Pinthong, J. Growths and carbon stocks of para rubber plantations on Phonpisai Soil Series in Northeastern Thailand. Rubber Thai J. 2012, 1, 1-18.

20. Maggiotto, S.R.; Oliveira, D.D.; Marur, C.J.; Stivari, S.M.S.; Leclerc, M.; Wagner-Riddle, C. Potential carbon sequestration in rubber tree plantations in the northwestern region of the Paraná State, Brazil. Acta Sci. Agron. 2014, 36, 239-245. [CrossRef]

21. Nizami, S.M.; Zhang, Y.P.; Sha, L.Q.; Zhao, W.; Zhang, X. Managing carbon sinks in rubber (Hevea brasilensis) plantation by changing rotation length in SW China. PLoS ONE 2014, 9, e115234. [CrossRef] [PubMed]

22. Tang, J.W.; Pang, J.P.; Chen, M.Y.; Guo, X.M.; Zeng, R. Biomass and its estimation model of rubber plantations in Xishuangbanna, Southwest China. Chin. J. Ecol. 2009, 28, 1942-1948.

23. Yang, J.C.; Huang, J.H.; Tang, J.W.; Pan, Q.M.; Han, X.G. Carbon sequestration in rubber tree plantations established on former arable lands in Xishuangbanna, SW China. Chin. J. Plant Ecol. 2005, 29, 296-303.

24. Cotta, M.K.; Jacovine, L.A.G.; Valverde, S.R.; Paiva, H.N.D.; Virgens Filho, A.D.C.; Silva, M.L.D. Economic analysis of the rubber-cocoa intercropping for generation of certified emission reduction. Rev. Árvore 2006, 30, 969-979. (In Portuguese) [CrossRef]

25. Cheng, C.M.; Wang, R.S.; Jiang, J.S. Variation of soil fertility and carbon sequestration by planting Hevea brasiliensis in Hainan Island, China. J. Environ. Sci. 2007, 19, 348-352. [CrossRef]

26. Fernandes, T.J.G.; Soares, C.P.B.; Jacovine, L.A.G.; Alvarenga, A.D.P. Quantification of carbon stored in the aerial part and roots of 12-year-old Hevea sp., in the "Zona da Mata Mineira". Rev. Árvore 2007, 31, 657-665. (In Portuguese). [CrossRef]

27. Sha, L.Q. Carbon Storage and Soil $\mathrm{CO}_{2}$ Efflux of Tropical Seasonal Rain Forest, Rubber Tree Plantation and Paddy Soil in Xishuangbanna. Ph.D. Thesis, Xishuangbanna Tropical Botanical Garden, University of Chinese Academy of Sciences, Beijing, China, 1 June 2008.

28. Peng, Y. Researches on Carbon Sequestration Function of Plant Subsystem in Rubber (Hevea brasiliensis) Plantation Ecosystem in Western Hainan. Master's Thesis, Hainan University, Haikou, China, 1 July 2010.

29. Zheng, Z.B.; Wang, X.; Zhou, Z.D.; Yang, H. Carbon storage and distribution law of the rubber forest ecological system in Danzhou of Hainan. Trop. Agric. Eng. 2010, 34, 45-50.

30. Egbe, A.E.; Tabot, P.T.; Fonge, B.A.; Bechem, E. Simulation of the impacts of three management regimes on carbon sinks in rubber and oil palm plantation ecosystems of South-Western Cameroon. J. Ecol. Nat. Environ. 2012, 46, 154-162.

31. Kongsager, R.; Napier, J.; Mertz, O. The carbon sequestration potential of tree crop plantations. Mitig. Adapt. Strateg. Glob. Chang. 2013, 18, 1197-1213. [CrossRef] 
32. Miao, X.L. Study on the Potential for Carbon Sequestration Fartificial PR107 Rubber Forest Ecosystem in Rubber Tree Planting Area of Qiongzhong of Hainan. Master's Thesis, Hainan University, Haikou, China, 1 July 2013.

33. Sun, Y. Simulation of Carbon Dynamic Change and Accumulation Process in Rubber Plantation of Xishaungbanna. Ph.D. Thesis, Xishuangbanna Tropical Botanical Garden, University of Chinese Academy of Sciences, Beijing, China, 1 June 2013.

34. Xiao, Z.W.; Wang, X.H.; Zheng, L.; Wang, X.L.; Gao, L.H.; Tang, J.W. Biomass and its allocation pattern of monoculture and mixed rubber-tree plantations in Xishuangbanna. J. Central South Univ. For. Technol. 2014, 34, 108-116.

35. Bert, D.; Danjon, F. Carbon concentration variations in the roots, stem and crown of mature Pinus pinaster (Ait.). Forest Ecol. Manag. 2006, 222, 279-295. [CrossRef]

36. Peichl, M.; Arain, M.A. Above-and belowground ecosystem biomass and carbon pools in an age-sequence of temperate pine plantation forests. Agr. Forest Meteorol. 2006, 140, 51-63. [CrossRef]

37. Zheng, W.J.; Bao, W.K.; Gu, B.; He, X.; Leng, L. Carbon concentration and its characteristics in terrestrial higher plants. Chin. J. Ecol. 2007, 26, 307-313.

38. Cao, J.X.; Wang, X.P.; Tian, Y.; Wen, Z.Y.; Zha, T.S. Pattern of carbon allocation across three different stages of stand development of a Chinese pine (Pinus tabulaeformis) forest. Ecol. Res. 2012, 27, 883-892. [CrossRef]

39. Zhou, Y.R.; Yu, Z.L.; Zhao, S.D. Carbon storage and budget of major Chinese forest types. Acta Phytoecol. Sin. 2000, 24, 518-522.

40. Wang, F.M.; Xu, X.; Zou, B.; Guo, Z.H.; Li, Z.A.; Zhu, W.X. Biomass accumulation and carbon sequestration in four different aged Casuarina equisetifolia coastal shelterbelt plantations in South China. PLoS ONE 2013, 8, e77449.

41. Zhang, H.; Song, T.Q.; Wang, K.L.; Du, H.; Yue, Y.M.; Wang, G.X.; Zeng, F.P. Biomass and carbon storage in an age-sequence of Cyclobalanopsis glauca plantations in southwest China. Ecol. Eng. 2014, 73, 184-191. [CrossRef]

42. Mao, R.; Zeng, D.H.; Hu, Y.L.; Li, L.J.; Yang, D. Soil organic carbon and nitrogen stocks in an age-sequence of poplar stands planted on marginal agricultural land in Northeast China. Plant Soil 2010, 332, 277-287. [CrossRef]

43. Fonseca, W.; Alice, F.E.; Rey-Benayas, J.M. Carbon accumulation in aboveground and belowground biomass and soil of different age native forest plantations in the humid tropical lowlands of Costa Rica. New For. 2012, 43, 197-211. [CrossRef]

44. Ming, A.; Jia, H.; Zhao, J.; Tao, Y.; Li, Y. Above-and below-ground carbon stocks in an indigenous tree (Mytilaria laosensis) plantation chronosequence in subtropical China. PLoS ONE 2014, 9, e109730. [CrossRef] [PubMed]

45. Pregitzer, K.S.; Euskirchen, E.S. Carbon cycling and storage in world forests: Biome patterns related to forest age. Glob. Chang. Biol. 2004, 10, 2052-2077. [CrossRef]

46. Song, Q.H.; Tan, Z.H.; Zhang, Y.P.; Sha, L.Q.; Deng, X.B.; Zhou, W.J.; Zhao, J.F.; Zhao, J.B.; Zhang, X.; et al. Do the rubber plantations in tropical China act as large carbon sinks? Forest 2014, 7, 42-47. [CrossRef]

47. Cleveland, C.C.; Taylor, P.; Chadwick, K.D.; Dahlin, K.; Doughty, C.E.; Malhi, Y.; Smith, W.K.; Sullivan, B.W.; Wieder, W.R.; Townsend, A.R. A comparison of plot-based satellite and Earth system model estimates of tropical forest net primary production. Glob. Biogeochem. Cycle 2015, 29, 626-644. [CrossRef]

48. Peltoniemi, M.; Mäkipää, R.; Liski, J.; Tamminen, P. Changes in soil carbon with stand age-an evaluation of a modelling method with empirical data. Glob. Chang. Biol. 2004, 10, 2078-2091. [CrossRef]

49. Tang, J.W.; Zhang, J.H.; Song, Q.S.; Cao, M.; Feng, Z.L.; Dang, C.L.; Wu, Z.L. A preliminary study on the biomass of secondary tropical forest in Xishuangbanna. Acta Phytoecol. Sin. 1998, 22, 489-498.

50. Ziegler, A.D.; Phelps, J.; Yuen, J.Q.; Webb, E.L.; Lawrence, D.; Fox, J.M.; Bruun, T.B.; Leisz, S.J.; Ryan, C.M.; Dressler, W.; et al. Carbon outcomes of major land-cover transitions in SE Asia: great uncertainties and REDD+ policy implications. Glob. Chang. Biol. 2012, 18, 3087-3099. [CrossRef]

(C) 2017 by the authors. Licensee MDPI, Basel, Switzerland. This article is an open access article distributed under the terms and conditions of the Creative Commons Attribution (CC BY) license (http://creativecommons.org/licenses/by/4.0/). 